\title{
The Importance of Agribusiness Five Sub-System in The Cocoa Development in West Sulawesi
}

\author{
Nurlina Harli $^{1 *}$, Irham $^{2}$, Jamhari ${ }^{2}$ \\ ${ }^{I}$ Postgraduate Agribusiness Management, Faculty of Agriculture, Universitas Gadjah Mada, Flora \\ Street, Bulaksumur, Caturtunggal, Depok District, Sleman Regency, Yogyakarta Province \\ ${ }^{2,3}$ Faculty of Agriculture, Universitas Gadjah Mada, Jl. Flora No. 1 Bulaksumur, Yogyakarta
}

Received: 21 September 2018; Revised: 27 September 2018; Accepted: 2 October 2018

\begin{abstract}
West Sulawesi Province is one of cocoa production centers in Indonesia. This study aims to determine: (1) Level of importance of criteria in cocoa agribusiness development, (2) Level of importance of subcriteria in cocoa agribusiness development, and (3) Choosing appropriate priority strategy in cocoa agribusiness development. Primary data and secondary data was used and analyzed using Analytical Hierarchy Process (AHP) with Expert Choice 11.0. Resulting analysis showed that the most important criterion in the development of cocoa agribusiness in the upstream subsystem, the following priorities respectively are marketing subsystem, cultivation subsystem, supporting subsystem, processing subsystem. The priority criterion in upstream agribusiness subsystem was on the subcriteria availability of cocoa seeds. Increasing cocoa production was the priority criterion in cultivation subsystem. The priority criterion in processing subsystem was subcriteria of capital availability. The Cocoa quality improvement was the priority in the marketing subsystem. The priority criterion in supporting subsystem was subcriteria of infrastructure improvement. The main priority of alternative strategy was to rejuvenate old plants using qualified plant material to increase production and quality of yield weighted as 0.241.
\end{abstract}

Keywords: agribusiness subsystem; Analytical Hierarchy Process (AHP); cocoa

\section{How to cite:}

Harli, N., Irham, \& Jamhari. (2018). The Importance of Agribusiness Five Sub-System in The Cocoa Development in West Sulawesi. HABITAT, 29(2), 84-91. https://doi.org/10.21776/ub.habitat.2018.029.2.10

\section{Introduction}

The agribusiness development is an approach in the agriculture development which does not only encompass agribusiness; but also includes the production, the distribution of input material instrument and agricultural service, as well as the distribution and agriculture product processing. Agribusiness system is a concept that places activities agriculture as a whole and comprehensive activity as well as a concept that can examine and answer various problems and challenge.(Marina \& Yulistia, 2015)

One of the imminent commodities of plantation sector is cocoa which has quite significant role for the national economy since the cocoa plantation provides working opportunities/job vacancies, a source of income, and nation's foreign exchange. In addition, cocoa also plays a role in enhancing the regional and

*Penulis Korespondensi

E-mail: nurlinaharlihasan@gmail.com agro-industry developments (Syamsuddin \& Muhammad, 2014). In 2015, the cocoa plantation has provided job opportunities and income sources for 1,699,617 farmers with 837,452 ha of plantation area and 652,397 ton of production (Directorate General of Plantation, 2017).

Various problems faced in the cocoa cultivation in West Sulawesi including the low level or plantation productivity due to the attack of cocoa pod borer (CPB), and the low quality of product will generate issues in the development of cocoa for the communities in the future of this region. Therefore, the comprehensive information regarding the condition of communities' cocoa cultivation is required to be discovered, thus, effective and efficient development for cocoa cultivation in the future will be able to be formulated. A higher consumption of cocoa either on national or foreign level will induce a bigger opportunity to establish a cocoa business both from the aspect of 
sufficient area availability and bank's funding that able to support the cocoa development for the West Sulawesi people. (Syamsuddin \& Muhammad, 2014)

In recent years, farmer's income has begun to decline as cocoa productivity declines. The limitations of other supporting factors are the limited supporting infrastructure for production and marketing interests indirectly affect farmer's income (Fatmawaty et al., 2015).

The identification of problem of cocoa agribusiness that will be analyzed in the research of strategic development for cocoa agribusiness in West Sulawesi is by determining the priority of agribusiness system that will be developed in accordance with the five sub-systems of cocoa agribusiness, namely the upstream sub-system, cultivation sub-system, processing/production sub-system, marketing sub-system, and supporting sub-system. ("Telaah Pustaka," 1998)

The final aim of this research is to discover the priority level of the strategic development for cocoa agribusiness in West Sulawesi Provinces according to the five sub-systems of cocoa agribusiness, namely the upstream sub-system, cultivation sub-system, processing/production sub-system, marketing sub-system, and supporting sub-system by using AHP.

\section{Method}

The respondents in this research were the representatives of stakeholders who understand the program of agribusiness development for cocoa commodity in West Sulawesi Province (Table 1.). The sample was taken purposively (purposive sampling).

Table 1. Respondent Sample

\begin{tabular}{llc}
\hline No & Sample & $\begin{array}{c}\text { Number } \\
\text { of } \\
\text { Sample } \\
\text { (People) }\end{array}$ \\
\hline 1. & $\begin{array}{l}\text { Agriculture Department of } \\
\text { West Sulawesi Province } \\
\text { 2he Research Center of } \\
\text { Agriculutre Technology of }\end{array}$ & 3 \\
3. $\begin{array}{l}\text { West Sulawesi } \\
\text { Department of Plantation of } \\
\text { Mamuju Regency }\end{array}$ & 4 \\
4. & $\begin{array}{l}\text { Department of Agriculture of } \\
\text { Polewali Mandar Regency } \\
\text { Cocoa Farm Group }\end{array}$ & 4 \\
\hline & Total & 50 \\
\hline
\end{tabular}

This research took place in June 2017 until July 2017 in West Sulawesi Province, precisely in two regencies, Polewali Mandar and Mamuju. The election of the two districts is based on the decision of the Regional Government of West Sulawesi Province which makes the two areas as the area of cocoa agribusiness development.

The assessment in this research was conducted through the utilization of expert choice 11 software. The steps in determining the strategic development for cocoa agribusiness used the Analytical Hierarchy Process explained as follows:

a. Arrangied the hierarchy structure of the problem, shown in figure 1.

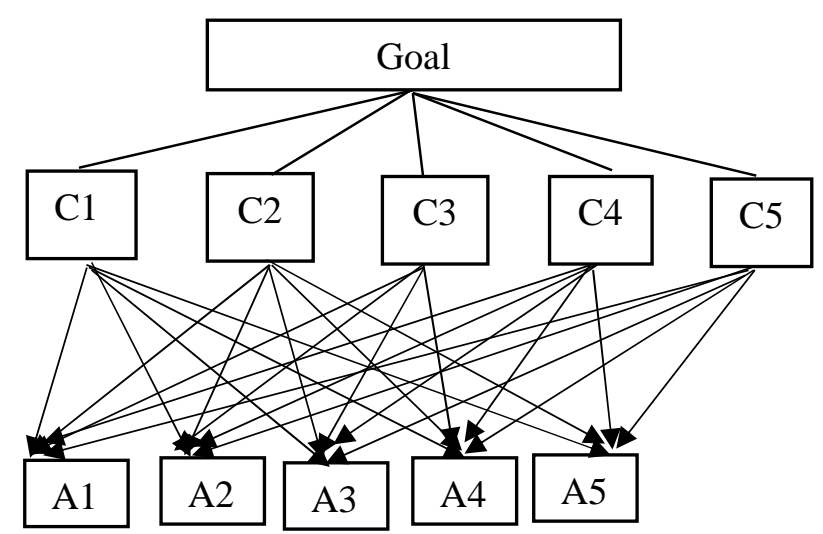

Figure 1. Hierarchycal structure

Attachment:

C1 : agriculture input subsystem

$C 2$ : cultivation subsystem

C3 : production subsystem

C4: marketing subsystem

C5: supporting subsystem

A1: Alternative strategy 1

A2: Alternative strategy 2

A3: Alternatif strategy 3

A4: Alternatif strategy 4

A5: Alternatif strategy 5

b. Created a pairwise comparison matrix that illustrates the influence relative contribution of each element towards each criterion above its level.

c. Calculated the weight/priority of each variable on level 1 (criteria) which were the agriculture input subsystem, cultivation sub-system, production sub-system, marketing sub-system, and supporting subsystem. The steps are:

1) Created a pairwise comparison of each criterion.

2) The results of respondent assessment were then calculated in average by using 
geometric mean. This process was conducted because AHP only requires one answer for comparison matrix.

3) The results of each pairwise comparison were presented in a pairwise comparison matrix.

4) Divided each element on the specific column with the column total value.

5) The results then normalized to acquire matrix eigenvector by averaging the total raw towards five criteria. The calculation above presents the eigenvector as the result of priority weighting of the five criteria towards the objectives.

6) Calculated the consistency ratio through the steps described as follows:

a) Multiplied the matrix value of pairwise comparison with the weight.

b) Multiplied the total row with the weight.

c) Calculated the $\lambda_{\max }$ by summing the multiplication results above which divided with n.

d. Calculated the consistency index.

e. Calculated the consistency ratio

f. After the weight of each criterion was discovered, the selected strategy was then determined. The selected strategy was the criteria that has the highest values.

The analytical hierarchy process is a method that formulates and analyses decisions by decomposing a complex multicriteria decisionmaking problem into a hierarchy of criteria and set of alternatives (Sharififar, Ghorbani, \& Karimi, 2013). According to Ngatawi \& Setyaningsih (2011), the basic principles of AHP include;

a. The criteria arrangement in hierarchy process. The criterion in this research is the cocoa agribusiness sub-system as the first level in the hierarchy form of factor (criteria) priority determination in cocoa agribusiness development.

b. Criteria assessment. The assessment is conducted through pairwise comparison. According to (Saaty, 2008), for various issues, 1-9 scales are the best scale to express opinion. The value and definition of qualitative opinion from the Saaty comparison scale can be seen in Table 2 . The priority determination. For each criterion, the pairwise comparison is required. The values of relative comparison from the entire alternative of criteria can be adjusted with the judgment that has been set to produce priority weight. The priority weight is calculated by manipulating through matrix or mathematic formulation solving.

Table 2. Pairwise Comparison Scales

\begin{tabular}{|c|c|}
\hline Scale & Information \\
\hline 1 & Both elements are equally important \\
\hline 3 & One element is a bit more important \\
\hline 5 & One element is more important \\
\hline 7 & One element is obviously more \\
\hline 9 & important \\
\hline $2,4,6,8$ & $\begin{array}{l}\text { One element is more important than } \\
\text { others }\end{array}$ \\
\hline & $\begin{array}{l}\text { The values between two consideration } \\
\text { values that adjacent }\end{array}$ \\
\hline $\begin{array}{l}\text { Reciprocal } \\
\text { Condition }\end{array}$ & $\begin{array}{l}\text { If } i \text { activity acquires one number } \\
\text { compared to the } j \text { activity, therefore, } j \\
\text { has a reciprocal value compared to } i\end{array}$ \\
\hline
\end{tabular}

Source: Saaty, (2008)

c. Logical consistency. The entire elements are group logically and warned consistently in accordance with a logic criterion.

\section{Result and Discussion}

\subsection{The Condition of Five Subsystems of Cocoa Agribusiness in West Sulawesi}

Agribusiness system is a system consisting of several subsystem, among of them: Upstream subsystem, cultivation subsystem, processing subsystem, marketing subsystem and supporting subsystem.

The cocoa cultivation is conducted through the processes of planting, treating, towards the harvesting. The aim of scheduled treatment for the farm is to minimize the pests' attack or cocoa disease (Rubiyo \& Siswanto, 2012). The pests' attack of cocoa in West Sulawesi is still dominated by cocoa pod borer (CPB), while the cocoa disease is commonly occurring in the event of fruit decay and fungus. The effort conducted by farmer to overcome the problems is through farm's treatment. However, the farmers who routinely perform treatment in West Sulawesi are usually the prominent farmers. The impact resulted from this is the prominent farmers conceive higher productivity rate compared to the non-prominent farmers. 


\subsection{Determining the Priority of the Development Strategy of Cocoa Agribusiness through the Five Sub- Systems}

In order to determine the priority of development strategy, in this research the Analytical Hierarchy Process (AHP) is conducted as one of the instrument that can be used for decision making in the planning process (Zulfiandri \& Marimin, 2012).

In determining the cocoa agribusiness development strategy in West Sulawesi, the problems faced are grouped into five aspects based on the five cocoa agribusiness sub-systems, namely; (1) Agriculture Input Sub-System; (2) Cocoa Cultivation Agribusiness Sub-System; (3) Cocoa Processing Sub-System; (4) Cocoa marketing Sub-System; (5) Supporting SubSystem. The problems and follow-up related to cocoa agribusiness development are summarized in the following hierarchy.

In order to determine the priority of the strategy in the development of cocoa agribusiness, then, the priority of the elements is determined by creating a paired comparison by comparing the elements in pairs according to predetermined criteria. The criteria used in this research are the five cocoa agribusiness subsystems. The pairwise comparison matrix made is filled by numbers to represent the relative importance/ significance of an element towards the other elements (Harisudin, 2013).

\subsection{The assessment of the criteria importance level}

In AHP method, the criteria are formulated in a hierarchy structure. The criteria and subcriteria in this research is the criteria and subcriteria in the determination of development strategies for cocoa agribusiness in West
Sulawesi Province. The results of the literature study are formulated in a hierarchy structure which divided into four levels, level 0 as an objective, the first level is the criteria in the determination of the development strategies for cocoa agribusiness, the second level is the subcriteria, while the third level is the alternative strategies that should be taken.

According to the AHP analysis, the criterion which become the priority in the development of cocoa agribusiness in West Sulawesi is the development of the subsystem criteria of upstream agribusiness with 0.270 weight. The high level of weight on the upstream subsystem criteria in the determination of development strategies of cocoa agribusiness in West Sulawesi is caused by the upstream agribusiness subsystem that includes the availability of subsidized fertilizers, the availability of pesticides and the easiness of acquiring production facilities and the availability of quality seeds.

The upstream subsystem as the main priority in which the agribusiness development on upstream subsystem is the agribusiness subsystem that conducts economy activities in producing and providing decent facilities of agriculture production in order to produce quality agriculture product. The importance of this subsystem is due to the necessity for the integration of various elements in the upstream subsystem to manifest a success agribusiness.

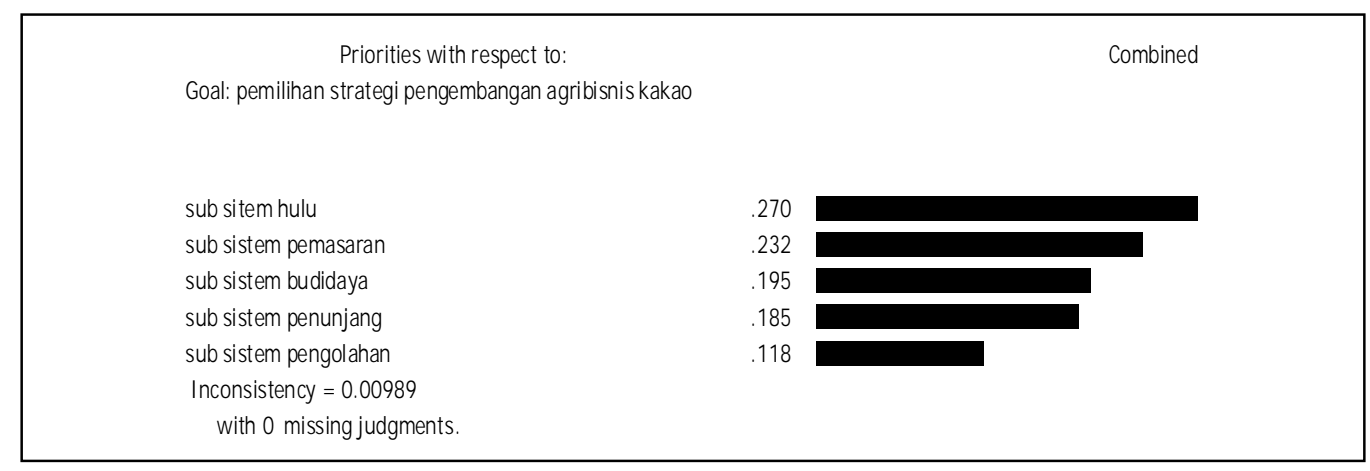

Figure 2. The results of primary data processing of the criteria priority determination 


\subsection{The assessment of the importance level of the sub-criteria of upstream subsystem}

From Figure 3., it can be known that the high priority factor in the development of cocoa agribusiness on upstream subsystem is the availability of cocoa seeds with 0.331 value, this condition is a result of 350,000 ha cocoa land which already in the old age, therefore, the revitalization of cocoa plant is required. The difficulty in acquiring cocoa seeds in West
Sulawesi has become the obstacle for cocoa farmers in West Sulawesi to perform the plant revitalization. This condition occurs because the farmers are forced to purchase certified cocoa seeds in West Sulawesi which also cause the high price of cocoa seeds. The provision of certified seeds is aimed for the seeds that distributed in the community to have quality and have been tested against all pests.

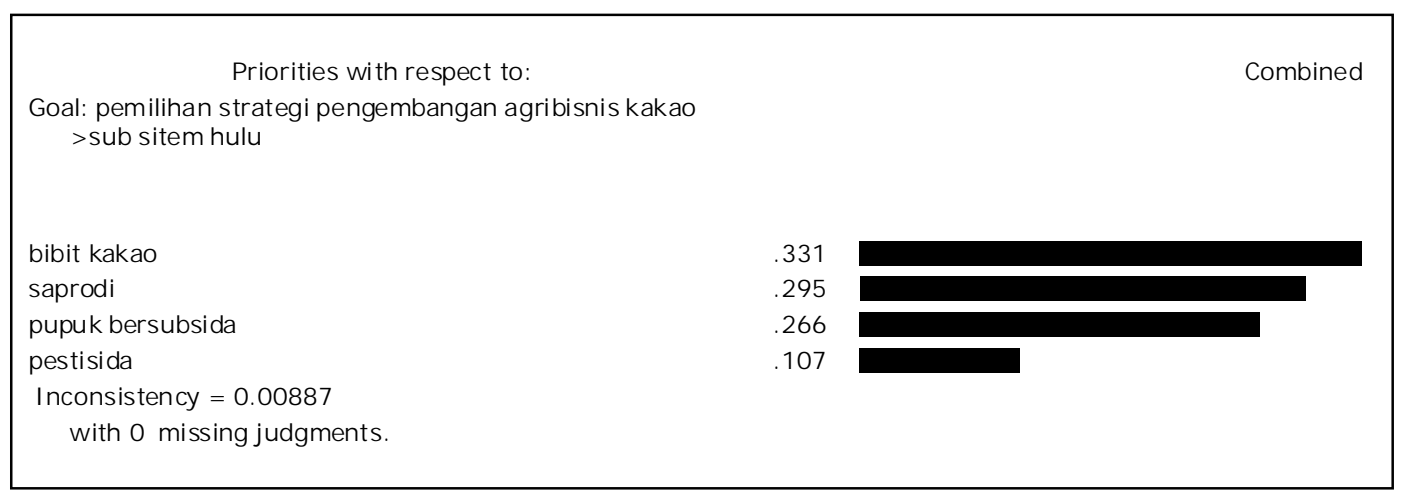

Figure 3. The results of primary data processing of the importance level assessment of the sub-criteria of upstream subsystem

\subsection{The assessment of the importance level of the sub-criteria of cultivation subsystem}

In Figure 4., it can be seen that the high priority factor in the development of cocoa agribusiness on cultivation subsystem is the criteria of the improvement of cocoa production with 0.339 value. This condition is a result of the improvement of cocoa production to fulfill the high demand of cocoa commodity to meet the industry demand for cocoa production or the export of cocoa seeds. At present, the cocoa production in West Sulawesi is having a decrease as what presented $n$ the 2015 BPS's data of West Sulawesi (Table 1. The development of area width of plant, production, and the number of cocoa farmers in West Sulawesi) which shows that the cocoa production has decreased around $5.54 \%$ from the previous year (2014).

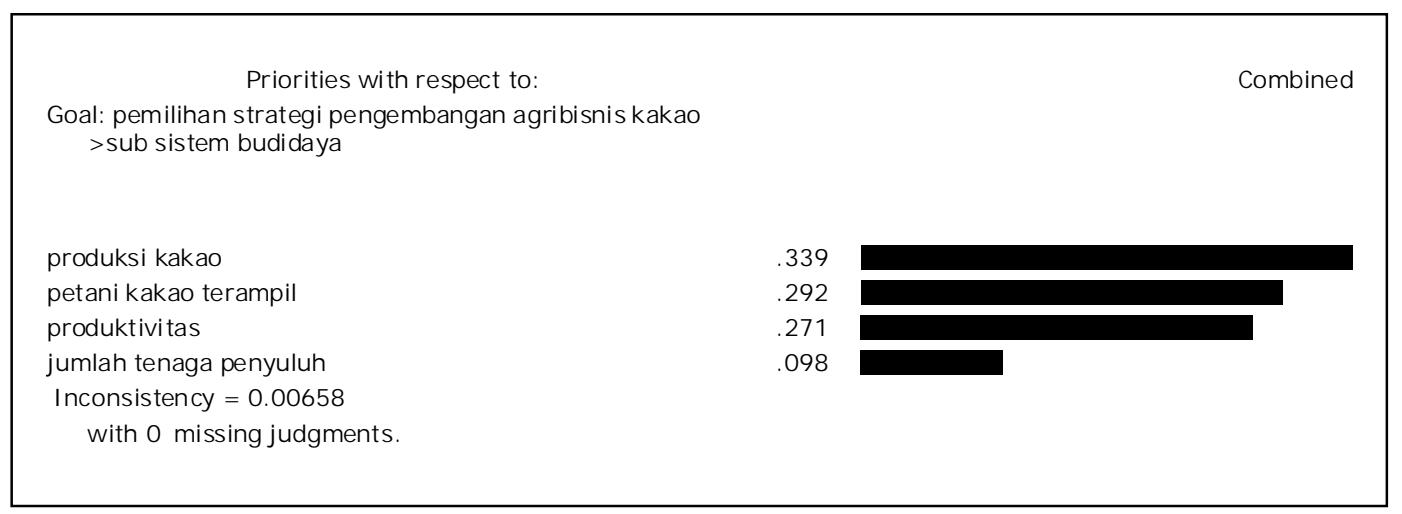


Figure 4. The results of primary data processing of the importance level assessment of the sub-criteria of cultivation subsystem

\subsection{The assessment of the importance level of the sub-criteria of production subsystem}

Figure 5. shows that the high priority factor in the development of cocoa agribusiness on production subsystem is the criteria of the availability of capital with 0.417 value. This condition is a result of the availability of capital in developing the cocoa agribusiness which highly important considering that the long chain of cocoa production has made farmers to require high amount of production cost which also defined as maintenance cost by the cocoa farmers. In addition, the cocoa plants which getting older have proved that a higher maintenance cost is required as well as the capital for farmers to revitalize their cocoa plants.

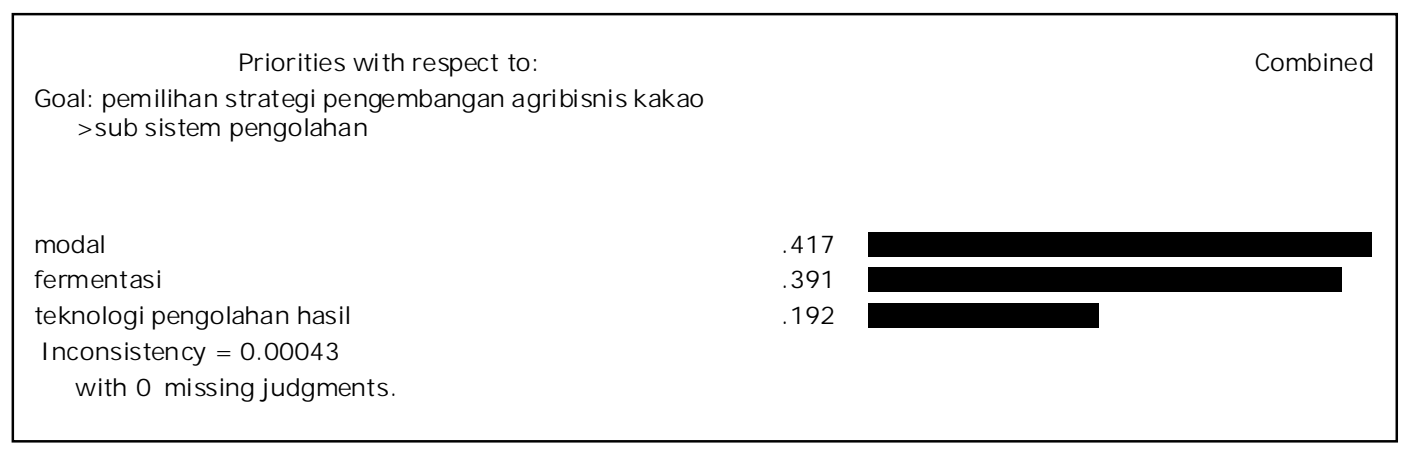

Figure 5. The results of primary data processing of the importance level assessment of the sub-criteria of production subsystem

\subsection{The assessment of the importance level of the sub-criteria of marketing subsystem}

There are several criteria in the marketing subsystem. The assessment of the importance level of sub-criteria of marketing subsystem will indicate a result that the priority in the subcriteria of marketing subsystem is on the criteria of the improvement of cocoa quality. The criterion that becomes priority can be seen in Figure 6. namely the criterion of the improvement of cocoa quality with 0.487 value.
The importance of improving the quality of cocoa in the development of cocoa agribusiness is due to the quality of cocoa which works as the supporting factor to acquired high profits in cocoa agribusiness. By improving the quality of cocoa, thus, the cocoa competitiveness in West Sulawesi as one of the central productions of cocoa in Indonesia will be more superior and the farmers will receive higher price if the issues of quality improvement and the continuity of cocoa production are immediately solved.

\begin{tabular}{|l|l|}
\hline \multicolumn{1}{|c|}{ Priorities with respect to: } & \\
Goal: pemilihan strategi pengembangan agribisnis kakao \\
$>$ sub sistem pemasaran
\end{tabular}


Figure 6. The results of primary data processing of the importance level assessment of the sub-criteria of marketing subsystem

\subsection{The assessment of the importance level of the sub-criteria of support subsystem}

The criteria on the support subsystem are measured to obtain the prioritized criteria. The development priority on the sub-criteria of the support subsystem as presented in Figure 7. is the improvement of infrastructures. Infrastructures are the important matter because the sufficient infrastructures to support the distribution and marketing processes are still unavailable. At present, not all the central productions of cocoa own proper road infrastructures, especially the central of cocoa at the hills. These inappropriate road infrastructures are not only causing high cost on product distribution but also on the production facility for the centrals of cocoa with improper road infrastructures.
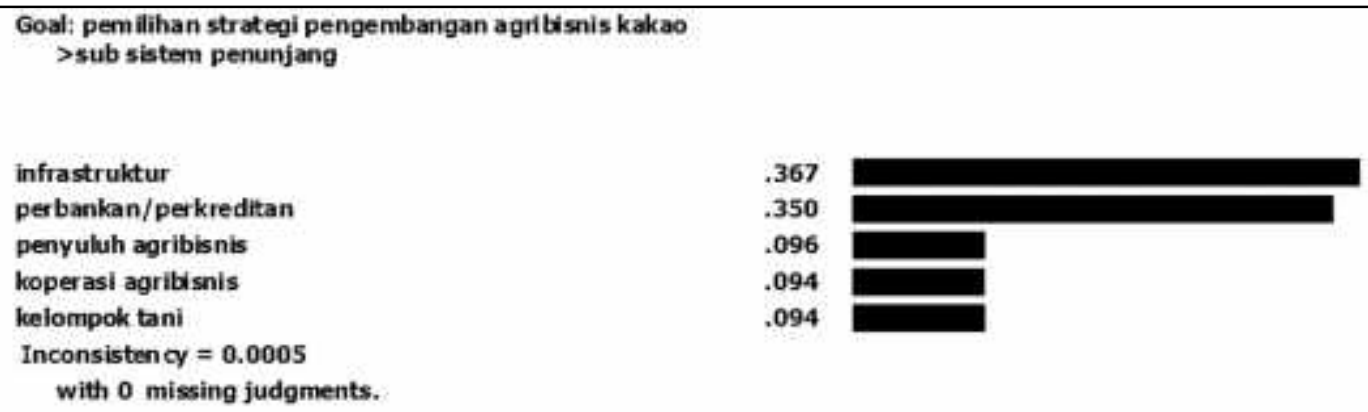

Figure 7. The results of primary data processing of the importance level assessment of the sub-criteria of support subsystem

\subsection{The Determination of the Priority of Development Strategies for Cocoa Agribusiness}

Comprehensively, according to the criteria and sub-criteria in the determination of the development strategies of cocoa agribusiness in West Sulawesi, thus, the alternative strategies that become the main priority are conducting the revitalization of old plants by using the eminent plants to tie the production and yield quality with
0.241 value as presented in Figure 7. The development of cocoa in West Sulawesi has implemented for more than 30 years which since 1982. The condition of plants which mostly in the old age and the rates of pest and disease attacks especially the cocoa pod borer that cause the production of cocoa to continuously decrease, therefore, the revitalization of cocoa plant is required.

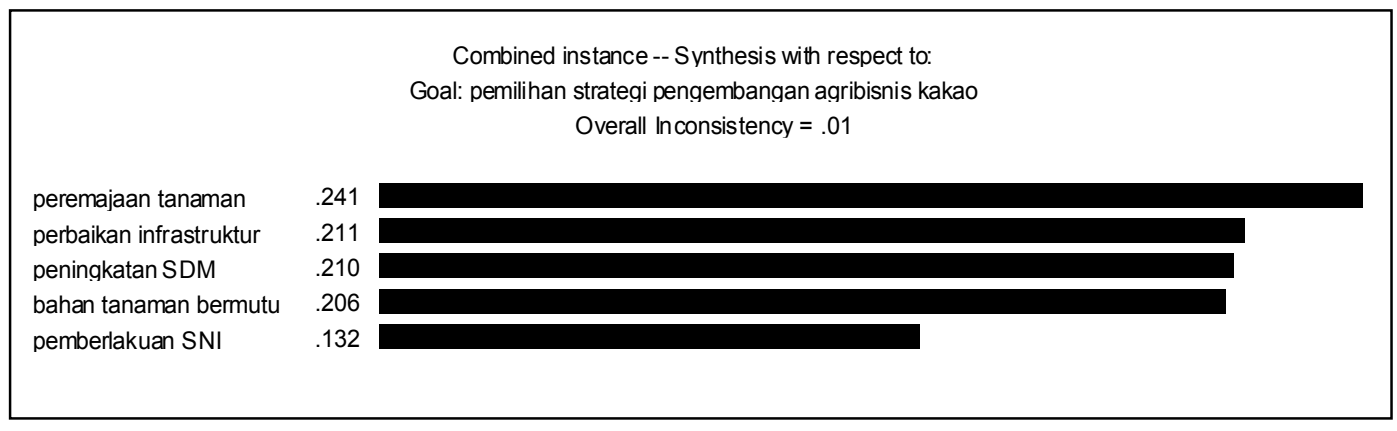

Figure 8. The results of primary data processing of the determination of the priority of development strategies of cocoa agribusiness

Available online at HABITAT website: http://www.habitat.ub.ac.id ISSN: 0853-5167 (p); 2338-2007 (e) 


\section{Conclusion}

The conclusions that can be summarized from the research of "The Importance Of Agribusiness Five Sub-System In The Cocoa Development In West Sulawesi" are as follows:

a. In the development of cocoa agribusiness in West Sulawesi, the priority in the development of cocoa agribusiness in West Sulawesi is the development of upstream agribusiness subsystem.

b. From the sub-criteria, what become the different priorities of each criterion are as follows:

1) The availability cocoa seeds becomes the priority in the upstream subsystem criteria.

2) The improvement of cocoa production becomes the priority in the cultivation subsystem criteria.

3) The availability of capital becomes the priority in the production subsystem criteria.

4) The improvement of cocoa quality becomes the priority in the marketing subsystem criteria.

5) The improvement of infrastructures becomes the priority in the support subsystem criteria.

c. From those five alternative strategies, the selected strategy which appropriate in developing the cocoa agribusiness of West Sulawesi is by performing the revitalization/rehabilitation of old plants through the use of eminent plants to improve the production and yield quality.

\section{References}

Direktorat Jenderal Perkebunan. (2017). Statistik Perkebunan Indonesia.

Fatmawaty, Baskoro, D. P. T., \& Widiatmaka. (2015). Strategi Pengembangan Komoditas Perkebunan Berbasis Daya Dukung Lahan di Kabupaten Majene. Jurnal Majalah Ilmiah Globe, 17(1), 25-32.

Harisudin, M. (2013). Pemetaan dan Strategi Pengembangan Agroindustri Tempe di Kabupaten Bojonegoro, Jawa Timur. Jurnal Teknologi Industri Pertanian, 23(2), 120-128.

Marina, I., \& Yulistia, I. (2015). Strategi Pengembangan Agribisnis Hasil Pertanian Melalui Inovasi dan Kreatifitas Menjadi Produk Unggulan di SMK Negeri 1 Pacet
Kabupaten Cianjur. Mimbar Agribisnis, 1(1), 45-54.

Ngatawi, \& Setyaningsih, I. (2011). Analisis Pemilihan Supplier Menggunakan Metode Analytic Hierarchy Process ( AHP ). Jurnal Ilmiah Teknik Industri, 10(1), 7-13.

Rubiyo, \& Siswanto. (2012). Peningkatan Produksi dan Pengembangan Kakao ( Theobroma cacao L. ) di Indonesia. Buletin RISTRI, 3(1), 33-48.

Saaty, T. L. (2008). Decision Making with The Analytic Hierarchy Process. International Journal of Services Sciences, 1(1), 83-98. https://doi.org/10.1504/IJSSCI.2008.01759 0

Sharififar, A., Ghorbani, H., \& Karimi, H. (2013). Integrated Land Evaluation for Sustainable Agricultural Production by Using Analytical Hierarchy Process. Agriculture, 59(3), 131-140. https://doi.org/10.2478/agri-2013-0012

Syamsuddin, \& Muhammad, H. (2014). Analisis Potensi dan Peluang Pengembangan Kakao di Sulawesi Barat. Jurnal Agros, 16(1), 92-101.

Telaah Pustaka. (1998).

Zulfiandri, \& Marimin. (2012). Strategi Pengembangan Agroindustri Kakao Berbasis Kelompok Tani di Propinsi Sumatera Barat. Jurnal Inovisi, 8(1), 1-13. 